\title{
The preparation temperature influences the physicochemical nature and activity of nanoceria
}

\author{
Robert A. Yokel ${ }^{*} 1, \S$, Wendel Wohlleben ${ }^{2}$, Johannes Georg Keller ${ }^{2}$, Matthew L. Hancock ${ }^{3}$, \\ Jason M. Unrine ${ }^{4}$, D. Allan Butterfield ${ }^{5}$ and Eric A. Grulke 3,9
}

\section{Full Research Paper}

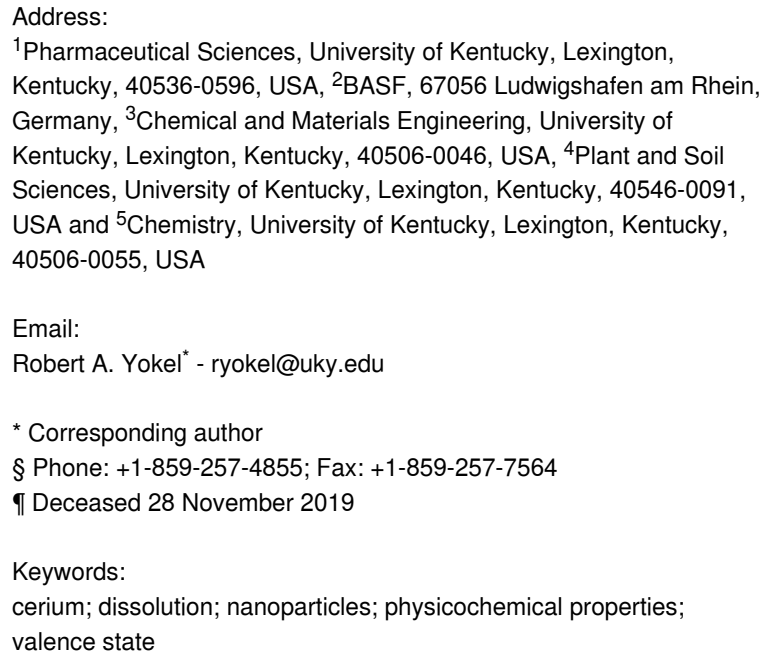

${ }^{1}$ Pharmaceutical Sciences, University of Kentucky, Lexington, Kentucky, 40536-0596, USA, ²BASF, 67056 Ludwigshafen am Rhein, Germany, ${ }^{3}$ Chemical and Materials Engineering, University of Kentucky, Lexington, Kentucky, 40506-0046, USA, ${ }^{4}$ Plant and Soil Sciences, University of Kentucky, Lexington, Kentucky, 40546-0091, USA and ${ }^{5}$ Chemistry, University of Kentucky, Lexington, Kentucky, 40506-0055, USA

Email:

Robert A. Yokel - ryokel@uky.edu

* Corresponding author

§ Phone: +1-859-257-4855; Fax: +1-859-257-7564

ๆ Deceased 28 November 2019

Keywords:

cerium; dissolution; nanoparticles; physicochemical properties;

valence state

Beilstein J. Nanotechnol. 2021, 12, 525-540. https://doi.org/10.3762/bjnano.12.43

Received: 26 January 2021

Accepted: 23 May 2021

Published: 04 June 2021

Associate Editor: C. T. Yavuz

(c) 2021 Yokel et al.; licensee Beilstein-Institut. License and terms: see end of document.

\begin{abstract}
Cerium oxide nanoparticles, so-called nanoceria, are engineered nanomaterials prepared by many methods that result in products with varying physicochemical properties and applications. Those used industrially are often calcined, an example is NM-212. Other nanoceria have beneficial pharmaceutical properties and are often prepared by solvothermal synthesis. Solvothermally synthesized nanoceria dissolve in acidic environments, accelerated by carboxylic acids. NM-212 dissolution has been reported to be minimal. To gain insight into the role of high-temperature exposure on nanoceria dissolution, product susceptibility to carboxylic acid-accelerated dissolution, and its effect on biological and catalytic properties of nanoceria, the dissolution of NM-212, a solvothermally synthesized nanoceria material, and a calcined form of the solvothermally synthesized nanoceria material (ca. 40, 4, and 40 nm diameter, respectively) was investigated. Two dissolution methods were employed. Dissolution of NM-212 and the calcined nanoceria was much slower than that of the non-calcined form. The decreased solubility was attributed to an increased amount of surface $\mathrm{Ce}^{4+}$ species induced by the high temperature. Carboxylic acids doubled the very low dissolution rate of NM-212. Nanoceria dissolution releases $\mathrm{Ce}^{3+}$ ions, which, with phosphate, form insoluble cerium phosphate in vivo. The addition of immobilized phosphates did not accelerate nanoceria dissolution, suggesting that the $\mathrm{Ce}^{3+}$ ion release during nanoceria dissolution was phosphate-independent. Smaller particles resulting from partial nanoceria dissolution led to less cellular protein carbonyl formation, attributed to an increased amount of surface $\mathrm{Ce}^{3+}$ species. Surface reactivity was greater for the solvothermally synthesized
\end{abstract}


nanoceria, which had more $\mathrm{Ce}^{3+}$ species at the surface. The results show that temperature treatment of nanoceria can produce significant differences in solubility and surface cerium valence, which affect the biological and catalytic properties of nanoceria.

\section{Introduction}

The long-term fate of engineered nanomaterials (ENMs), which could profoundly influence their biological effects, is not well understood. After uptake into phagolysosomes, which have a $\mathrm{pH}$ value of ca. 4.5, there is the potential for dissolution, changing the physicochemical, and potentially the biological, identity of ENMs.

Nanoceria are a family of metal oxide ENMs used industrially, as catalysts in diesel fuel, abrasives in chemical mechanical planarization, in integrated circuit manufacture, as structural supports for catalysts for fuel synthesis applications, in solid oxide fuel cells, and in rechargeable batteries [1,2]. Cerium oxide was selected by the OECD Working Party on Manufactured Nanomaterials as one of 13 representative manufactured nanomaterials for safety testing to create an understanding of the kind of information about intrinsic nanomaterial properties that may be relevant for exposure and effects assessment [3]. A nanoceria material, NM-212, produced by Umicore, has been studied to address the OECD objective.

Pulmonary NM-212 exposure for up to 90 days in rats resulted in pulmonary inflammation and genotoxicity with little evidence of clearance [4-8]. The European Union funded a comprehensive two-year whole-body combined chronic toxicity/carcinogenicity inhalation study in female rats exposed to 0 , $0.1,0.3,1$, or $3 \mathrm{mg} / \mathrm{m}^{3} \mathrm{NM}-212$, six hours daily on five consecutive working days per week (EU FP7 project 'NANoREG', Grant Agreement number 310584). Lung cerium burden after three, twelve, and 24 months of exposure positively correlated with exposure time and nanoceria concentration, with deposition fractions of $12 \%, 15 \%, 14 \%$, and $8 \%$, and predicted clearance half-lives of $86,114,164$, and 200 days [9]. These studies showed that pulmonary exposure to NM-212 could lead to longterm biological persistence and have adverse consequences and raised the question whether its method of preparation and solubility are contributing factors.

In contrast to the results with NM-212, other nanoceria have been demonstrated to have therapeutic potential for multiple conditions with an oxidative stress/inflammation component, including cancer, radiation damage, bacterial infection, sepsis, wounds, stroke-induced ischemia, retinal degeneration, and neurodegenerative diseases [10]. Other reviews provide more information on nanoceria synthesis methods and the resulting physicochemical properties of the products as well as the beneficial biological effects and human diseases that could poten- tially be treated [11], and the physicochemical properties that mediate the effects of nanoceria, its biochemical properties, biosynthesis, and its major biomedical applications, including biosensors [12]. Additional applications are cited in the introduction of [13]. These beneficial results have been obtained with nanoceria prepared by precipitation or solvothermal synthesis.

There are many reports of nanoceria synthesis, producing a myriad of products with different physicochemical properties tailored to their application. NM-212 was prepared as a nanoceria representative of those used in industrial applications. Nanoceria prepared for industrial applications are often exposed to high temperature (calcined), which increases particle size and produces crystalline particles with a predominance of surface $\mathrm{Ce}^{4+}$ [14-18]. NM-212 has been reported to have a primary particle size of 20 to $40 \mathrm{~nm}$ and a predominance of surface $\mathrm{Ce}^{4+}$ (Supporting Information File 1, Table S1). In contrast, nanoceria demonstrated to have therapeutic potential are typically prepared by procedures that do not include calcination, resulting in primary particles ca. $5 \mathrm{~nm}$ in diameter and with a predominance of surface $\mathrm{Ce}^{3+}$ (Supporting Information File 1, Table $\mathrm{S} 1$ ). Nanoceria are autocatalytically redox-active, cycling between $\mathrm{Ce}^{3+}$ (anti-oxidative) and $\mathrm{Ce}^{4+}$ (pro-oxidative) species. A higher temperature during nanoceria preparation is generally associated with more nanoceria-induced pro-oxidative effects [19] and would be expected to produce a nanoceria form with more $\mathrm{Ce}^{4+}$ and less ability to autocatalytically cycle between $\mathrm{Ce}^{4+}$ and $\mathrm{Ce}^{3+}$.

Early reports stated that nanoceria were insoluble or did not demonstrate significant solubility (Supporting Information File 1, Table S2). However, when studied for sufficient time it has been shown that some nanoceria dissolve in acidic media, accelerated by carboxylic acids, including a ca. $5 \mathrm{~nm}$ solvothermally synthesized nanoceria prepared for biological assessment. Although there have been some investigations of NM-212 that found very low solubility, none investigated concurrent carboxylic acid exposure or addressed why the dissolution of NM-212 is so low. The rate and extent of nanoceria solubility can influence resultant effects, which are greater from the released cerium ions than from nanoceria [20-23]. Given that nanoceria prepared for industrial applications, such as NM-212, are typically calcined, it was hypothesized that the low solubility of NM-212 is a product of high-temperature exposure. NM-212 was prepared by precipitation [7,24], but the synthesis process has not been reported and could not be discovered by 
the authors. The JRC Nanotechnology team support was unable to provide synthesis procedure information (personal communication to R. Yokel, February 10, 2020). Given the diversity of nanoceria products with different physicochemical properties, which are influenced by their preparation procedures, this lack of information hinders the interpretation of the influence of the NM-212 preparation on its effects. This limitation also applies to reports of effects following pulmonary exposure to other commercially supplied nanoceria prepared by proprietary methods [25-32].

The objective of the present studies was to determine the longterm dissolution of NM-212 (as a representative nanoceria material prepared for industrial applications) compared to a solvothermally synthesized nanoceria material (demonstrated to have pharmaceutical applications), the influence of carboxylic acids and immobilized phosphate on their dissolution, the influence of nanoceria after partial dissolution on a selected biological effect, and the surface reactivity. Based on reports of very limited NM-212 dissolution and physicochemical differences between nanoceria synthesized for industrial and biological applications, the former often including calcination and producing larger particles, it was hypothesized that the long-term dissolution of NM-212 would be slower than that of a solvothermally synthesized nanoceria material. Given that cerium forms very stable complexes with phosphate but phosphate inhibits nanoceria dissolution, it was hypothesized that phosphates not in direct contact with nanoceria would create a sink for released cerium ions and increase the nanoceria dissolution rate. Assuming that NM-212 was calcined to a crystalline form with fewer oxygen vacancies and exhibits, therefore, a predominance of surface $\mathrm{Ce}^{+4}$, compared to a solvothermally synthesized nanoceria material with more oxygen vacancies, which produce a preponderance of surface $\mathrm{Ce}^{+3}$, it was hypothesized the NM-212 would have less catalytic activity.

Another nanoscale ceria, produced for OECD-suggested safety testing, NM-211, was included in some of the present studies for comparison to NM-212 and the solvothermally synthesized nanoceria material. Its size and percentage of surface $\mathrm{Ce}^{+4}$ are intermediate between NM-212 and the tested solvothermally synthesized nanoceria material [33].

Nanoceria dissolution was determined using two methods, a continuous flow system (CFS) and a dialysis system. The influence of immobilized phosphate on the nanoceria dissolution rate was determined by addition of two phosphate-containing resins to the dialysis system. The influence of nanoceria dissolution on its biological identity was assessed as the protein carbonyl level in response to partially dissolved nanoceria. The catalytic potential was assessed using a reactivity assay.

\section{Experimental Materials}

NM-211 and NM-212 were obtained from the European Commission Joint Research Centre Institute for Health and Consumer Protection repository of reference materials from the OECD sponsorship program. The solvothermally synthesized nanoceria material was prepared using a hydrothermal method [34]. Briefly, 0.25 M cerium chloride heptahydrate and $0.25 \mathrm{M}$ citric acid monohydrate were added to $1.5 \mathrm{M}$ ammonium hydroxide, stirred, and autoclaved for $24 \mathrm{~h}$ at $50{ }^{\circ} \mathrm{C}$ then $24 \mathrm{~h}$ at $80{ }^{\circ} \mathrm{C}$. The product was dialyzed against $110 \mathrm{mM} \mathrm{pH} 7.4$ citric acid for $120 \mathrm{~h}$, replacing the dialysate every $24 \mathrm{~h}$, then dialyzed against DI water to remove citric acid and ionic cerium for an additional $72 \mathrm{~h}$, replacing the dialysate every $24 \mathrm{~h}$. The product was extensively characterized. It was a citrate-coated $4.2 \mathrm{~nm}$ ceria [35]. Lanthanides (LN) resin $(100$ to $150 \mu \mathrm{m})$ was obtained from Eichrom Technologies LLC, Lisle, IL, 60532. Hydroxyapatite (Bio-Gel HTP, 10 to $90 \mu \mathrm{m}$ ) was obtained from Bio-Rad. Cerium was obtained as an Aldrich ICP/DCP standard. RAW 264.7 (murine macrophage) cells were obtained from ATCC. Human blood serum was acquired from Sigma Aldrich (P2918-100 mL).

\section{Physicochemical characterization of NM-212}

The NM-212 sample was physicochemically characterized to verify and expand on prior characterizations. Transmission electron microscopy (TEM) and high-angle annular dark-field scanning transmission electron microscopy (HAADF-STEM) were conducted of NM-212 dispersed in DI water, sonicated for $10 \mathrm{~min}$ in a bath, and captured on 300 mesh lacey carbon copper grids dipped into the dispersion for approximately $5 \mathrm{~s}$ and dried overnight at room temperature. Electron microscopy was performed on a Thermo Scientific Talos F200X operated at an accelerating voltage of $200 \mathrm{keV}$. Images were recorded with a Ceta CCD camera. The mean and Feret diameters and area, and their standard deviation, minimum, and maximum, of one hundred particles were calculated using ImageJ software. Energy-dispersive X-ray spectroscopy (EDS) and electron energy loss spectroscopy (EELS) were conducted using Thermo Scientific's SuperX G2 and Gatans' Enfinium ER, respectively. Thermogravimetric analysis (TGA) (PerkinElmer TGA7) was used to determine the organic weight percent. This was repeated three times. TGA runs were completed under a nitrogen atmosphere to prevent the oxidation of organic matter. The sample was heated from 20 to $125{ }^{\circ} \mathrm{C}$ at $10{ }^{\circ} \mathrm{C} / \mathrm{min}$, held at $125{ }^{\circ} \mathrm{C}$ for $30 \mathrm{~min}$ to release physiosorbed water, and then heated to $900{ }^{\circ} \mathrm{C}$ at $10{ }^{\circ} \mathrm{C} / \mathrm{min}$. Fouriertransform infrared spectroscopy (FTIR) (Nicolet 6700 FTIR with a diamond ATR crystal) was used to detect organic functional groups on the ENM surface. Thirty-two scans were completed. 


\section{Nanoceria calcination}

Two samples ( 6.5 and $6.7 \mathrm{mg}$ ) of solvothermally synthesized nanoceria, described in Supporting Information File 1, Table $\mathrm{S} 1$, were calcined by heating in porcelain crucibles in a muffle furnace to $900{ }^{\circ} \mathrm{C}$ at a ramp rate of ca. $10{ }^{\circ} \mathrm{C} / \mathrm{min}$, then held for $3 \mathrm{~h}$. The product was characterized by electron microscopy performed on the Thermo Scientific Talos F200X described above. The primary particle diameter was estimated from 100 particles.

\section{Nanoceria dissolution}

The continuous flow system has been described [36,37]. It consists of phagolysosomal simulant fluid (Aleks Stefaniak's PSF medium at $\mathrm{pH} 4.5$ [38]), the flow-through cell, a flow regulating pump, and an autosampler. In the PSF reservoir, ultrahigh molecular weight polyethylene (UHMWPE) filters prevent clogging of the ultrafiltration membrane in the flow cell. For the standard conditions, $1 \mathrm{mg}$ of ENM was placed on a 5,000 MWCO, $47 \mathrm{~mm}$ cellulose triacetate membrane (Stedim Biotech GmbH, Göttingen, Germany, 14529-47-D) and inserted into the flow-through cell (BOLA, Bohlender GmbH, Germany, N1682-08). Over seven days, the ENM was exposed to a continuous $2 \mathrm{~mL} / \mathrm{h}$ PSF flow at $37{ }^{\circ} \mathrm{C}$. During this time, ten samples were drawn, and the eluate subsequently analyzed for its elemental concentration as described in section "Cerium quantification".

The dialysis system has been described $[39,40]$. Nanoceria ( $500 \mu \mathrm{g}$ cerium as nanoceria in $1 \mathrm{~mL}$ ) was loaded into Slide-ALyzer $^{\mathrm{TM}}$ dialysis cassettes with $2 \mathrm{kD}$ MWCO regenerated cellulose membranes $(66203)$ immersed in a $200 \mathrm{~mL}$ bath at pH 4.5 made iso-osmotic with sodium nitrate. Cassette/beaker systems were housed in a rotary shaking incubator at $37{ }^{\circ} \mathrm{C}$ rotated at $60 \mathrm{rpm}$. Dissolution was determined from the bath cerium concentration measured weekly for $2688 \mathrm{~h}$ (16 weeks). Citric and lactic acids (110 $\mathrm{mM}$ in the baths), previously shown to accelerate nanoceria dissolution [39,40], were studied. All conditions were studied in duplicate. To test the hypothesis that the slower dissolution of NM-212 was due to elevated temperature exposure during its preparation, the dissolution of calcined samples of the solvothermally synthesized nanoceria was compared to the noncalcined form

\section{Nanoceria dissolution in the presence of immobilized phosphates}

Two immobilized phosphates were studied to assess their effect on the dissolution of solvothermally synthesized nanoceria. NM-212 was not studied as it did not appreciably dissolve. LN resin, developed for extraction chromatography, containing di(2-ethylhexyl) orthophosphoric acid as the metal complexing group, and hydroxyapatite (HTP) were studied. Initial experiments were conducted to verify their ability and capacity to complex ionic cerium. LN resin $(7.5,40$, or $75 \mathrm{mg})$ was added to duplicate $15 \mathrm{~mL}$ tubes containing $10 \mathrm{~mL} \mathrm{pH} 4.5$ or $\mathrm{pH} 7$ isoosmotic citrate and $500 \mu \mathrm{g}$ ionic cerium. The tubes were gently agitated at $37{ }^{\circ} \mathrm{C}$ and aliquots of $75 \mu \mathrm{L}$ were withdrawn after 0 , $0.5,1,2,4,6$, and $24 \mathrm{~h}$ for cerium quantitation. The results showed that 40 and $75 \mathrm{mg} \mathrm{LN}$ resin complexed more than $50 \%$ of the cerium ions within $0.5 \mathrm{~h}$ at $\mathrm{pH}$ 4.5. This experiment was repeated with 40 or $75 \mathrm{mg} \mathrm{LN}$ resin and sampling up to $3360 \mathrm{~h}$. This experiment was similarly conducted with $75 \mathrm{mg}$ HTP at pH 4.5 and pH 7 with samples collected up to $2016 \mathrm{~h}$.

To test the hypothesis that phosphates not in direct contact with nanoceria increase the nanoceria dissolution rate, $\mathrm{LN}$ resin and HTP were added to the dialysis system bath $(75 \mathrm{mg}, \mathrm{LN}$ at $\mathrm{pH}$ 4.5 and HTP at $\mathrm{pH}$ 7.4). The cassette contained $500 \mu \mathrm{g}$ cerium (as solvothermally synthesized nanoceria in $1 \mathrm{~mL}$ ). In an initial experiment, samples were withdrawn from duplicate cassettes five times from 1344 to $4704 \mathrm{~h}$. The cerium concentration in the cassettes decreased much faster at $\mathrm{pH} 4.5$ than at $\mathrm{pH} 7.4$, consistent with prior results $[39,40]$. The experiment was repeated with additional duplicate systems containing no $\mathrm{LN}$ resin at $\mathrm{pH} 4.5$ and no $\mathrm{HTP}$ at $\mathrm{pH}$ 7.4. Cassette samples were withdrawn weekly for 16 weeks (from 168 to $2688 \mathrm{~h}$ ).

\section{Cerium quantification}

Samples were digested with 2:1 $\mathrm{HNO}_{3} / \mathrm{H}_{2} \mathrm{O}_{2}$ in Teflon vessels in a CEM MARS Express microwave digestion system. Terbium was added as an internal standard. Samples were analyzed compared to standards. At the University of Kentucky, cerium was quantified by inductively coupled plasma mass spectrometry (ICP-MS; Agilent 7500cx or 7900, Agilent Technologies, Inc., Santa Clarita, CA) [41]. Spiked samples (cerium average recovery was $106 \%$ ) and blank samples (that were below the detection limit) were included. At BASF, the eluate was diluted 10- to 100-fold and quantified by ICP-MS (Perkin Elmer Nexion 2000b, Perkin Elmer Inc., Waltham, USA) with a limit of detection of $0.01 \mathrm{ppb}$. Measurements were conducted in triplicate and averaged.

\section{Determination of dissolution half-life and dissolution rate}

The dissolution half-life was calculated as described [37,42] as a curve fitting of the cumulative dissolved mass, expressed as an inverse relationship of decreasing solid retained $\left(\mathrm{CeO}_{2}\right.$ mass $)$ as $\left(M_{\text {ion }}(T)-M_{0}\right) / M_{0}$, where $M_{\text {ion }}$ is the amount of dissolved nanoceria and $M_{0}$ is the initial mass loading, and plotted as a function of the time on a semi-log scale. The dissolution rate $(k)$ was determined from the slope of the line as shown below, normalized to the surface area determined using the 
Brunauer-Emmett-Teller method, $A_{\mathrm{BET}}$, and converted to percent per day of $M_{0}$. Dissolution rate and half-life $\left(t_{1 / 2}, 50 \%\right.$ dissolved) are inversely related and can be expressed as given for first-order modeling in ISO 19057:2017 [43,44]:

$$
k=\frac{\ln 2}{A_{\mathrm{BET}} \cdot t_{1 / 2}} .
$$

\section{Biological identity of the as-prepared and partially dissolved solvothermally synthesized nanoceria}

Solvothermally synthesized nanoceria was partially dissolved by loading nanoceria $(1.3 \mathrm{~mL}$ of $19,540 \mu \mathrm{g} / \mathrm{mL}$ cerium) into Slide-A-Lyzer ${ }^{\mathrm{TM}}$ cassettes immersed in $200 \mathrm{~mL}$ of $\mathrm{pH} 4.5$ isoosmotic citric acid, and agitated as described above in section "Nanoceria dissolution". Samples withdrawn from a cassette after 75,102 , and 152 days were dialyzed against water, as described above in the synthesis of the solvothermally synthesized nanoceria. The hydrodynamic diameter (Smoluchowski's approximation) of the as-prepared- (as-loaded) and the partially dissolved nanoceria was determined by dynamic light scattering (DLS) using a Brookhaven 90Plus Particle Size Analyzer. The zeta potential $(0.5 \mathrm{mg} / \mathrm{mL})$ from $\mathrm{pH} 0.5$ to 13 , adjusted with nitric acid and sodium hydroxide, was determined using an Anton Paar Litesizer 500 Particle Analyzer. The instrument was equipped with a $40 \mathrm{~mW}$ laser emitting at $658 \mathrm{~nm}$. One hundred runs were completed in sequence with a $30 \mathrm{~s}$ equilibration time at $25^{\circ} \mathrm{C}$. Based on the bath cerium concentration after 75,102 , and 152 days the nanoceria was dissolved to $38 \%, 47 \%$, and $93 \%$, respectively. In an initial experiment, RAW 264.7 cells were exposed for $24 \mathrm{~h}$ to $0,1,3,10,30$, or $100 \mu \mathrm{g} / \mathrm{mL}$ of the 75 day partially dissolved nanoceria. The cells were washed twice with Dulbecco's PBS, pelleted, and stored at $-74{ }^{\circ} \mathrm{C}$. Cells were homogenized in the presence of protease inhibitors $(4 \mu \mathrm{g} / \mathrm{mL}$ leupeptin, $4 \mu \mathrm{g} / \mathrm{mL}$ pepstatin A, and $5 \mu \mathrm{g} / \mathrm{mL}$ aprotinin). Protein was measured using the bicinchoninic acid method. Protein carbonyls were determined as described in [45]. Briefly, samples were derivatized with $10 \mathrm{mM}$ 2,4 -dinitrophenylhydrazine solution in $12 \%$ sodium dodecyl sulfate for $20 \mathrm{~min}$ at room temperature, neutralized, and blotted onto a nitrocellulose membrane for slot-blot analysis with an anti-DNPH rabbit antibody and secondary anti-rabbit IgG alkaline phosphatase antibody, using reagents from the OxyBlot Protein Oxidation Detection Kit (Millipore). The initial experiment was repeated with as-prepared and 75, 102, and 152 day partially dissolved nanoceria.

\section{Nanoceria reactivity}

Oxidative stress, as mass-based biological oxidative damage (mBOD), and surface-based biological oxidative damage (sBOD), of NM-211, NM-212, and the solvothermally synthe- sized nanoceria was determined using the ferric reduction ability of serum assay (FRAS) as described in [46]. The materials were tested in triplicate, at a concentration of $1 \mathrm{~m}^{2} \mathrm{ENM} / \mathrm{mL}$ serum.

\section{Results \\ Physicochemical characterization of NM-212}

TEM, conducted at a higher resolution than previously reported, showed NM-212 to be crystalline and cubic or triangular with clearly defined edges (Figure 1). The solvothermally synthesized nanoceria is also crystalline but hexagonal and smaller (Figure $1 \mathrm{~b}$ of [35]). The estimated diameter and variability of NM-212 (Table 1) are consistent with prior reports (Supporting Information File 1, Table S1) and the size is consistent with nanoceria calcined at temperatures above $600{ }^{\circ} \mathrm{C}$ [15-17]. The relative intensities of the $\mathrm{M} 5$ and $\mathrm{M} 4$ peaks are directly related to the $\mathrm{Ce}^{3+}$ and $\mathrm{Ce}^{4+}$ concentrations, respectively $[47,48]$. EELS showed that the NM-212 particle edge and core exhibit ca. $90 \% \mathrm{Ce}^{4+}$ (Figure 2), consistent with nanoceria calcined at $T \geq 400{ }^{\circ} \mathrm{C}$ [18]. In contrast, the surface of the solvothermally synthesized nanoceria exhibits primarily $\mathrm{Ce}^{3+}$ (Figure $3 \mathrm{~b}$ of [35]). TGA showed an average weight loss from 20 to $400{ }^{\circ} \mathrm{C}$ of ca. $1.3 \%$ for NM-212 (Figure 3), indicative of some organic surface coating, as previously reported [7]. The TGA weight loss for the solvothermally synthesized nanoceria was much greater (ca. 15\%) due to its citrate coating (Figure 8 of [35]). FTIR, not previously reported for NM-212, showed small peaks at ca. 1630,1420 , and $1320 \mathrm{~cm}^{-1}$, attributed to $\mathrm{N}-\mathrm{O},-\mathrm{COOH}$, or hydroxy groups; probably $\mathrm{COOH}$ and the stretching mode of $\mathrm{O}-\mathrm{H}$ bonds; and either $-\mathrm{CH}$ or $\mathrm{C}-\mathrm{O}-\mathrm{C}$, respectively $[16,49,50]$ (Figure 4). Due to the citrate coating on the solvothermally synthesized nanoceria, the FTIR spectrum shows additional large peaks at 1535 and $1365 \mathrm{~cm}^{-1}$ (Figure 10 of [35]). EDS showed co-localization of not only cerium and oxygen for both NM-212 (Figure 1) and the solvothermally synthesized nanoceria (Figure 2 of [35]), but also carbon, as previously reported [7], and sodium (Figure 1) were found.

\section{Calcined nanoceria physicochemical characterization}

TEM showed the calcined nanoceria was crystalline with a primary particle diameter of $41 \pm 11 \mathrm{~nm}$ (mean \pm S.D.) and had formed large aggregates (Figure 5). EELS showed a predominance of $\mathrm{Ce}^{4+}$ (Figure 6). HAADF-EDS confirmed the presence of cerium and oxygen and showed some nitrogen and sodium but no carbon above the background.

\section{Nanoceria dissolution}

Under identical conditions of continuous flow testing at $\mathrm{pH} 4.5$, the solvothermally synthesized nanoceria dissolved significantly faster than NM-212 or NM-211 (Figure 7), calculated from 

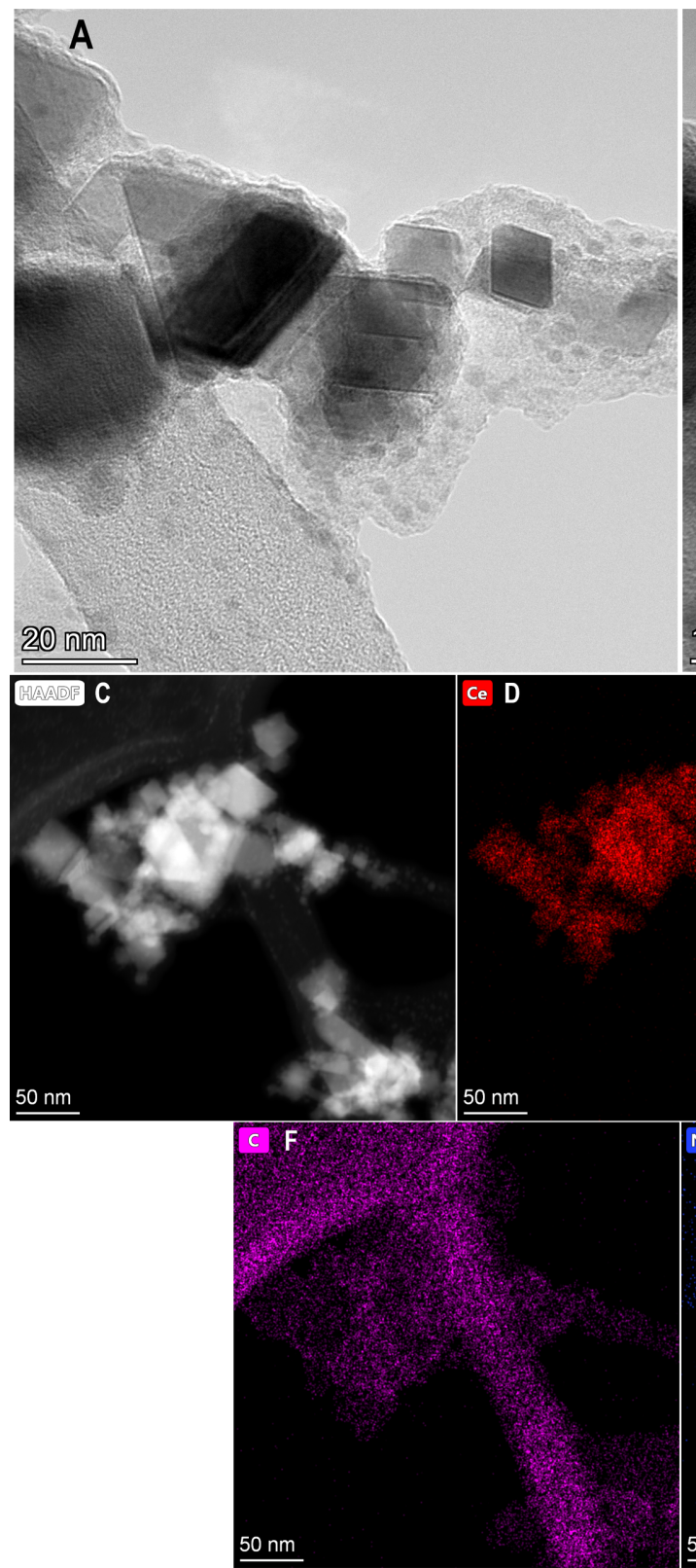

B

$10 \mathrm{~nm}$

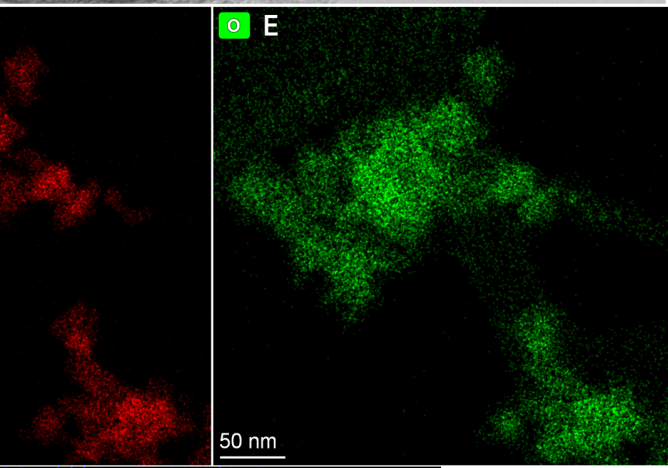

Na G

$50 \mathrm{~nm}$

Figure 1: Transmission electron microscopy and high-angle annular dark-field scanning transmission electron microscopy images of NM-212 and its chemical composition determined by energy-dispersive X-ray spectroscopy. (A, B) TEM images, (B) is a part of (A) at higher magnification. (C) HAADF STEM image. (D-G) EDS-determined chemical composition.

Table 1: NM-212 diameter and area determined from TEM images.

$\begin{array}{llll} & \text { estimated diameter }(\mathrm{nm}) & \text { Feret diameter }(\mathrm{nm}) & \left.\mathrm{area}(\mathrm{nm})^{2}\right) \\ \text { mean } & 22 & 29 & 484 \\ \text { S.D. } & 11 & 15 & 490 \\ \text { minimum } & 8 & 11 & 55 \\ \text { maximum } & 59 & 85 & 2775\end{array}$



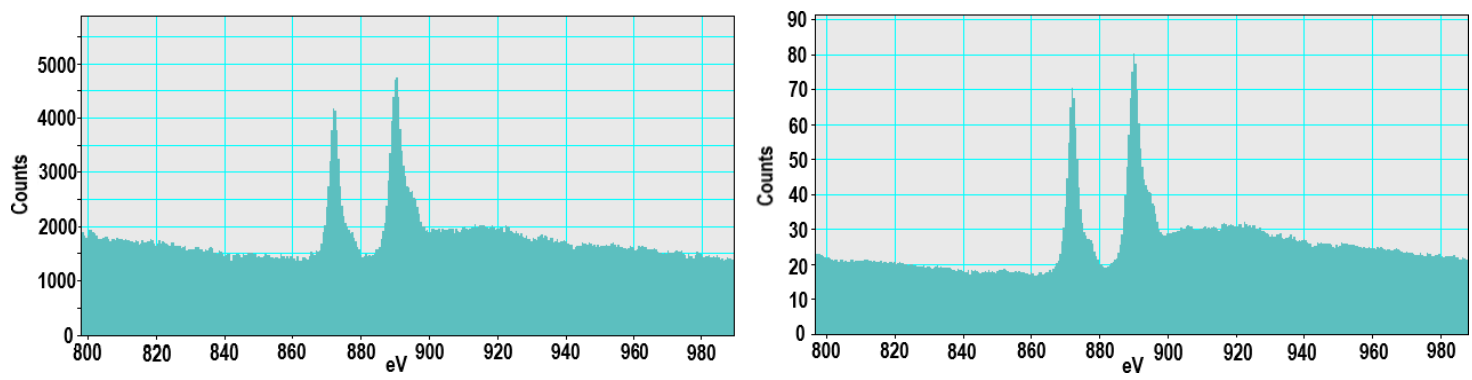

Figure 2: NM-212 cerium valence determined by electron energy loss spectroscopy. The left image was obtained at the edge, the right image at the ENM core.

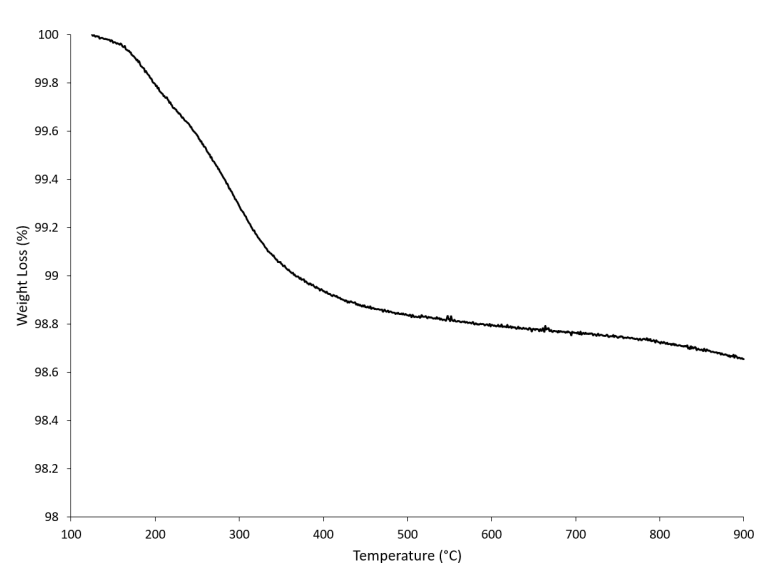

Figure 3: Thermogravimetric analysis of NM-212. Representative and near average of three determinations.

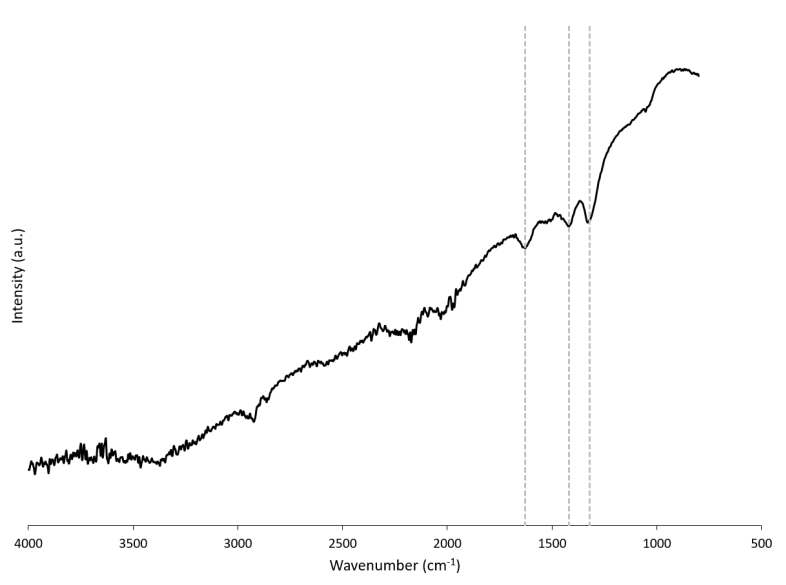

Figure 4: Non-baseline corrected Fourier-transform infrared spectroscopy of NM-212 with peaks indicated by dashed lines at 1630, 1420, and $1320 \mathrm{~cm}^{-1}$.

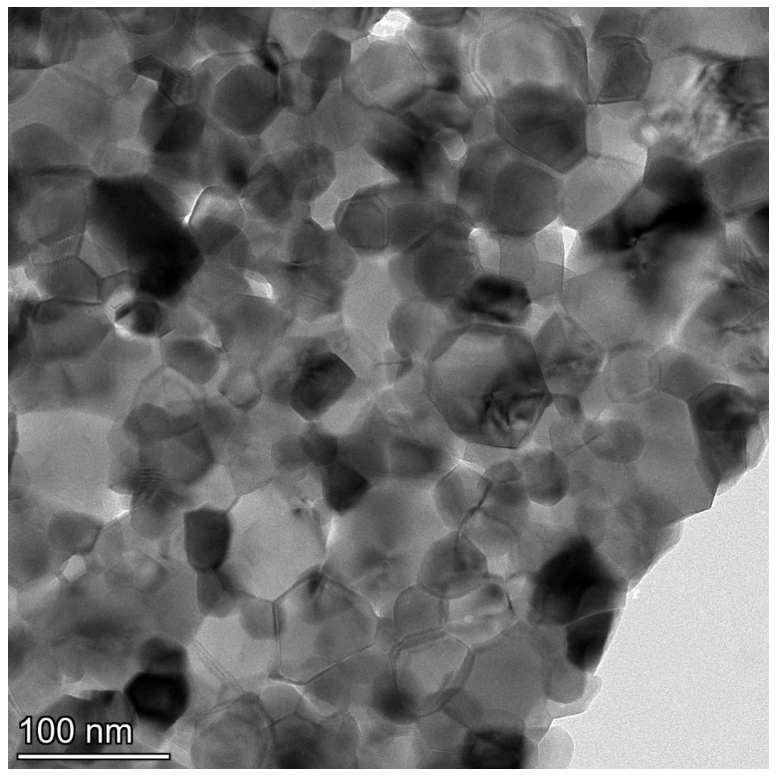

Figure 5: Transmission electron microscopy image of calcined solvothermally synthesized nanoceria.

ICP-MS determination of dissolved ions. The difference between NM-212 and the solvothermally synthesized nanoceria is less dramatic if the results are expressed as a dissolution rate in which the difference in specific surface area is factored out. Assuming first-order kinetics, as successfully fit to other, more soluble, ENMs [36], the half-lives of the solvothermally synthesized nanoceria and of NM-212 are ca. 50 and ca. 2250 days, respectively (Table 2).

The cerium concentration in the bath of the dialysis system that contained solvothermally synthesized nanoceria in the cassette increased over time, indicating nanoceria dissolution. Citric and lactic acid increased the dissolution rate (Table 2), as previously reported $[39,40]$. The rate of NM-212 dissolution was 


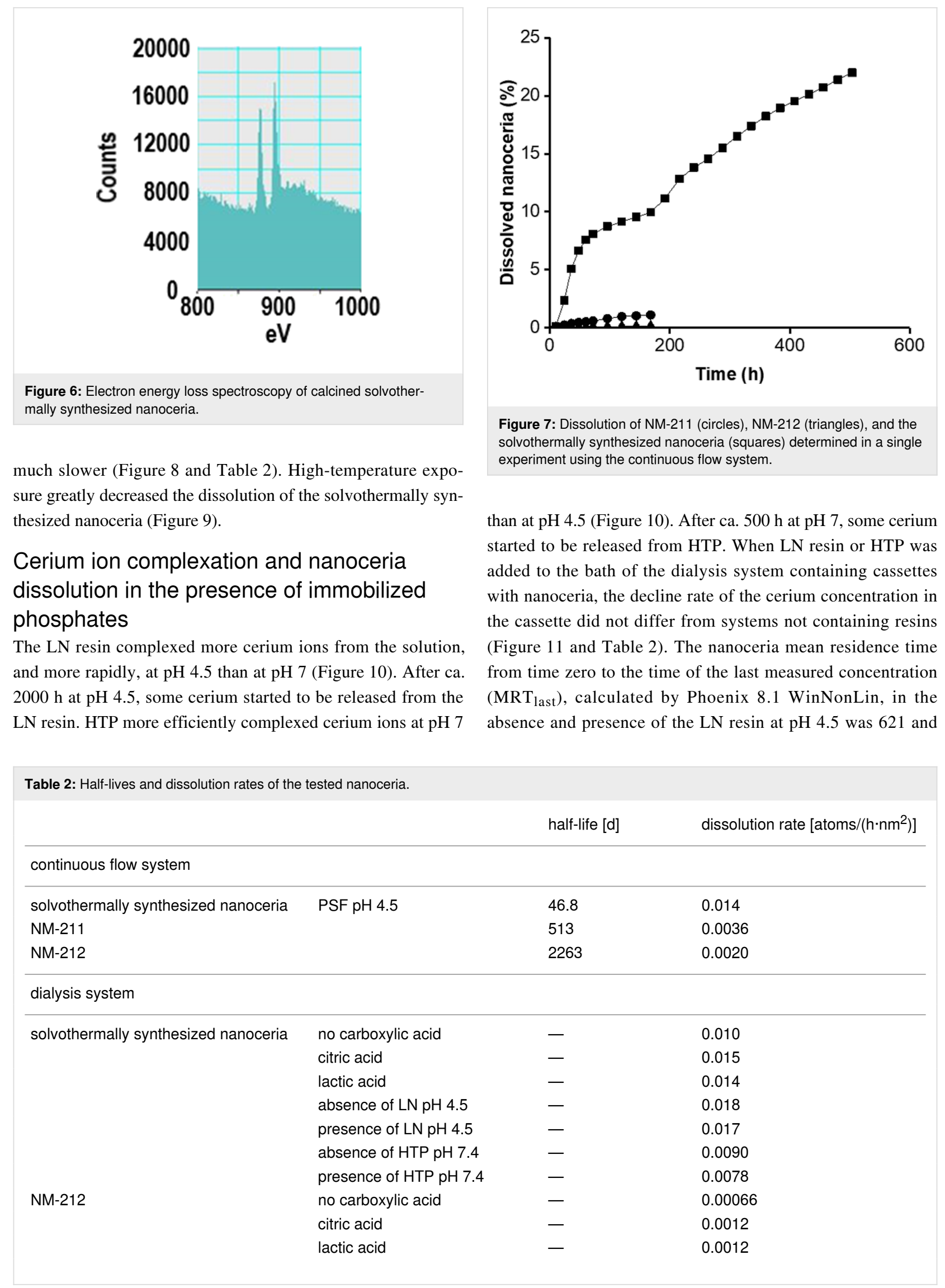




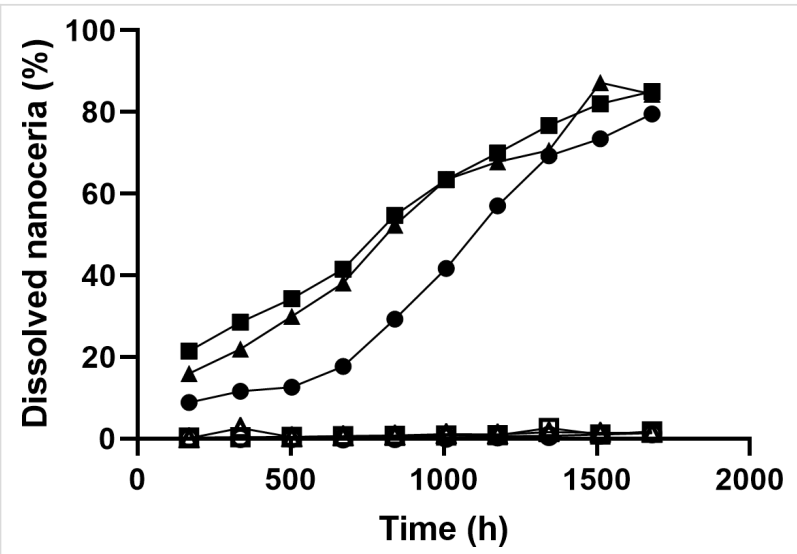

Figure 8: Dissolution of NM-212 and the solvothermally synthesized nanoceria, in the absence and presence of citric and lactic acids, determined by the dialysis system. NM-212 in the absence and presence of citric and lactic acids are indicated by open circles, squares, and triangles, respectively. Solvothermally synthesized nanoceria in the absence and presence of citric and lactic acids are indicated by solid circles, squares, and triangles, respectively. Results are the mean of two observations.

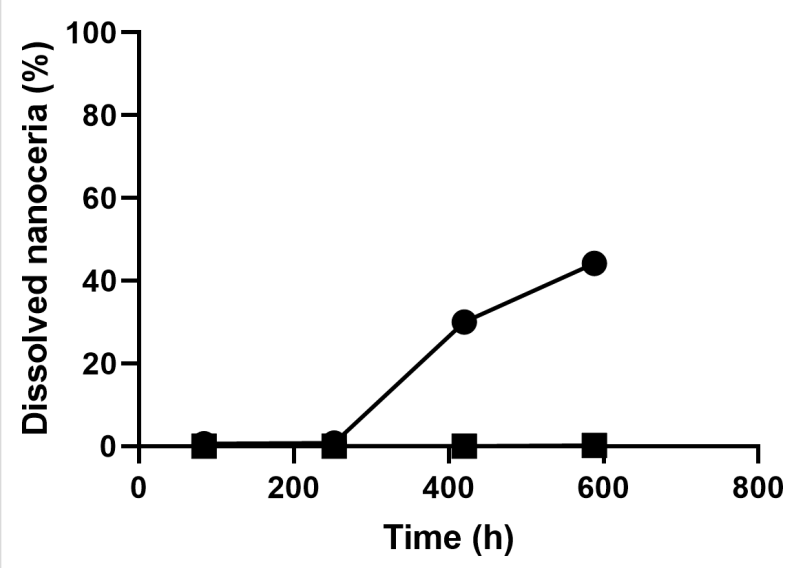

Figure 9: High-temperature exposure decreased the dissolution of solvothermally synthesized nanoceria. Solid circles represent solvothermally synthesized nanoceria (non-calcined) and squares the calcined form. Results are the mean of two observations.

$625 \mathrm{~h}$, respectively, and in the absence and presence of HTP at pH 7.4, it was 786 and 797 h, respectively.

\section{Biological identity of the as-prepared and partially dissolved solvothermally synthesized nanoceria}

The hydrodynamic diameter (as surface area) of the nanoceria materials after 75,102 , and 152 days of dissolution was 18 to $34 \mathrm{~nm}, 18$ to $27 \mathrm{~nm}$, and more than $1000 \mathrm{~nm}$, respectively, compared to 6.5 to $13.2 \mathrm{~nm}$ for the as-prepared nanoceria. After 75 days of dissolution, the surface charge was $-9 \mathrm{mV}$, compared to the as-prepared nanoceria surface charge of $-40 \mathrm{mV}$, suggesting the loss of the citrate coating.
RAW 264.7 cell exposure to the as-prepared solvothermally synthesized nanoceria showed a trend toward higher protein carbonyl production compared to cells not exposed to nanoceria. The initial experiment of cells exposed to nanoceria that had been partially dissolved for 75 days showed a trend toward lower protein carbonyl production than that of cells exposed to the as-prepared nanoceria (results not shown). When this experiment was repeated, the as-prepared nanoceria increased the production of protein carbonyls. Nanoceria partially dissolved after 75,102 , and 152 days increased the production protein carbonyls to a lesser extent than as-prepared nanoceria (Figure 12).

\section{Nanoceria reactivity}

The mBOD and sBOD values for NM-211, NM-212, and the solvothermally synthesized nanoceria are reported in Table 3 with information used to interpret the differential solubility and reactivity. The solvothermally synthesized nanoceria exhibited the highest reactivity with little difference between NM-211 and NM-212.

\section{Discussion}

\section{Comparison of the physicochemical properties}

TEM images obtained for this study suggest that NM-212 is crystalline and cubic or triangular with clearly defined edges (Figure 1). The solvothermally synthesized nanoceria is also crystalline but hexagonal. A previous determination of the primary particle size of NM-212 yielded an average of 20 to $40 \mathrm{~nm}$ with a very wide size range (Supporting Information File 1, Table S1). The size determination in this study showed an average diameter of $22 \mathrm{~nm}$ with a range of 11 to $59 \mathrm{~nm}$. In contrast, the solvothermally synthesized nanoceria had a primary particle diameter of $4 \mathrm{~nm}$. A prior characterization of the surface oxidation state of NM-212 showed a great predominance of $\mathrm{Ce}^{4+}$ (Supporting Information File 1, Table S1) which was also found in the present study at the edge and core of the particles (Figure 2). In contrast, the solvothermally synthesized nanoceria cerium surface valence was predominantly $\mathrm{Ce}^{3+}$ (Supporting Information File 1, Table S1), consistent with the increase in $\mathrm{Ce}^{3+}$ as the size of nanoceria decreases [53]. The calcined solvothermally synthesized nanoceria cerium had a predominance of $\mathrm{Ce}^{4+}$ (Figure 6). NM-212 was reported to be uncoated [24]. However, it was found that its surface had organic contaminations, shown by thermogravimetric analysis $(<0.7 \%$ of the material [7]). Further investigation with XPS, which has an information depth between 3 and $10 \mathrm{~nm}$, indicated $80 \%$ carbon atoms on the surface. Photoelectron energies suggested the contamination could be an ester with a long alkyl chain. The contamination was a very thin, homogeneous layer 
LN resin $40 \mathrm{mg}, \mathrm{pH} 4.5$
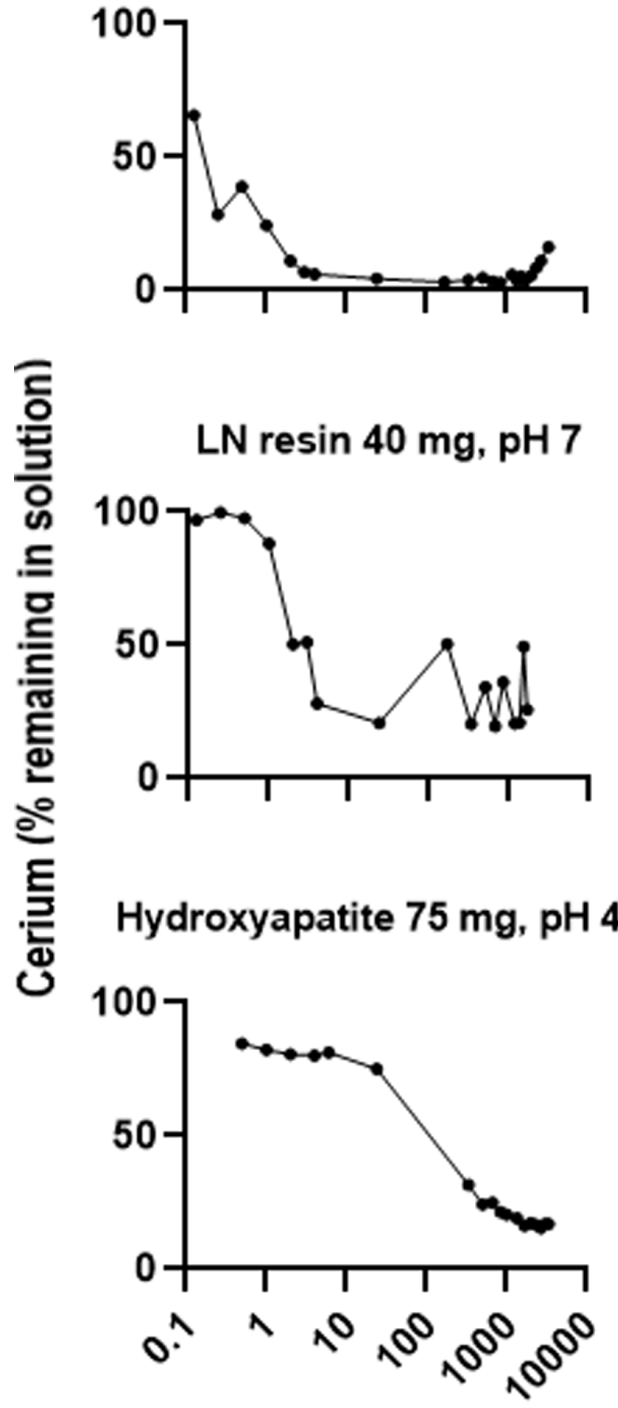

LN resin $75 \mathrm{mg}, \mathrm{pH} 4.5$

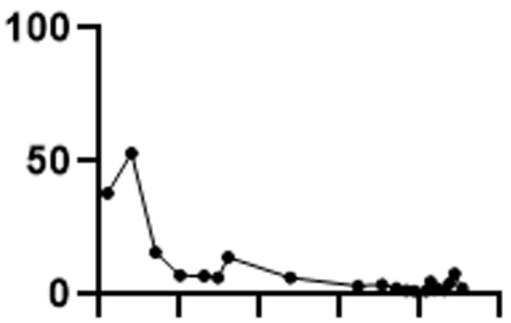

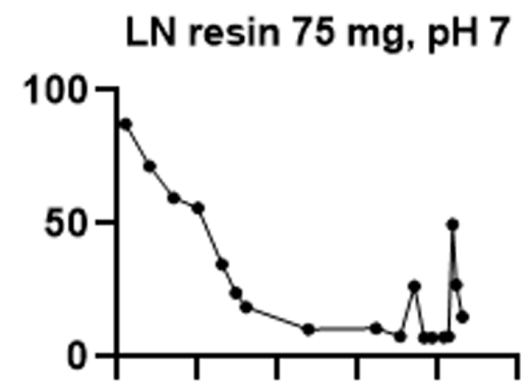

Hydroxyapatite $75 \mathrm{mg}, \mathrm{pH} 7$

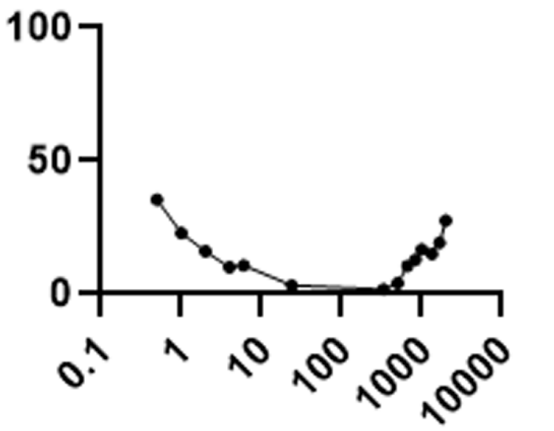

Time (h)

[7]. TGA conducted in the present study showed an average weight loss of $1.3 \%$ (Figure 3 ) which can be attributed to a small amount of surface contamination. The comparison with the TGA-induced $5 \%$ weight loss of the solvothermally synthesized nanoceria at $125^{\circ} \mathrm{C}$ due to outgassing of water, including surface hydroxy groups, suggests that NM-212 was calcined. The solvothermally synthesized nanoceria also exhibited a weight loss of ca. $10 \%$ due to its citrate coating. EDS revealed some carbon and sodium on the particle surface of NM-212 (Figure 1). FTIR showed small peaks at 1630, 1420, and $1320 \mathrm{~cm}^{-1}$, attributed to $\mathrm{N}-\mathrm{O}$ or $-\mathrm{COOH}$, probably $-\mathrm{COOH}$, and either $-\mathrm{CH}$ or $\mathrm{C}-\mathrm{O}-\mathrm{C}$, respectively, which would be consistent with the presence of an ester and an alkyl chain
(Figure 4). In contrast, solvothermally synthesized nanoceria was coated with, on average, a monolayer of citrate, intentionally applied to inhibit agglomeration [35]. It is assumed that the citrate coating was dissolved as surface cerium ions were solubilized. The reduction in absolute zeta potential of the partially dissolved nanoceria supports this assumption.

The high fraction of $\mathrm{Ce}^{4+}$ in the calcined solvothermally synthesized nanoceria is comparable to that of NM-212 and expected after calcination [18]. The increased primary particle size is consistent with reports that found a temperature-dependent increase of nanoceria particle size, including $44 \mathrm{~nm}$ particles when heated to $1000{ }^{\circ} \mathrm{C}$ [15-17]. The predominance of $\mathrm{Ce}^{3+}$ on 


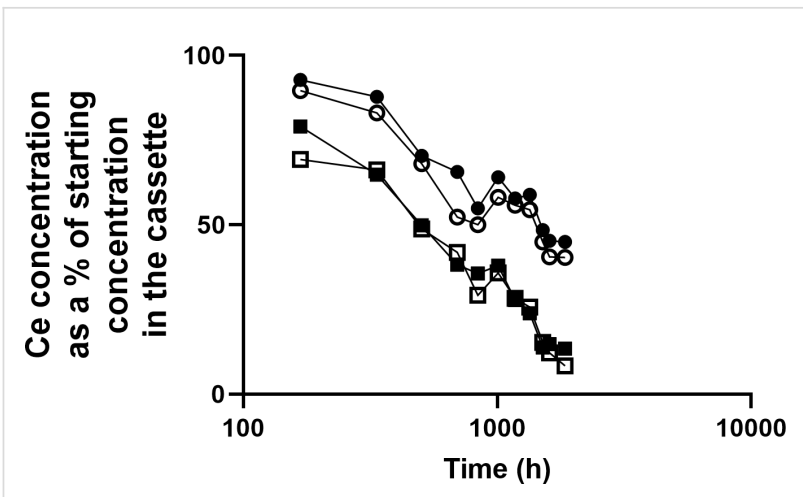

Figure 11: Addition of $L N$ resin and HTP to the dialysis bath did not affect nanoceria dissolution. Solid circles: with HTP at $\mathrm{pH} 7.4$, open circles: without HTP at $\mathrm{pH} 7.4$, solid squares: with $\mathrm{LN}$ resin at $\mathrm{pH} 4.5$, open squares: without $\mathrm{LN}$ resin at $\mathrm{pH} 4.5$. Results are the mean of two observations.

the surface of the non-calcined solvothermally synthesized nanoceria is consistent with its small size [54] and Figure 13

\section{Dissolution}

Prior studies reported a solubility of less than $3 \%$ of NM-212 up to $28 \mathrm{~d}(672 \mathrm{~h})$ in multiple media (see Introduction). The present results extend the dissolution time to 16 weeks ( $2688 \mathrm{~h}$ ). Also, they include the addition of carboxylic acids that have been shown to accelerate nanoceria dissolution (Figure 8 and Table 2) and a direct comparison of the solubility of NM-212 to a commonly used solvothermally synthesized nanoceria by two methods conducted by different research teams. After 16 weeks, ca. $1.5 \%$ of the cerium in NM-212 was in the dialysis system bath, compared to ca. $80 \%$ from the solvothermally synthesized nanoceria. Several factors could contribute to the much more rapid dissolution of the solvothermally synthesized nanoceria. The size difference may contribute to the dissolution difference. The solvothermally synthesized nanoceria is smaller than NM-212 or the calcined solvothermally synthesized nanoceria (4.2, 40, and $41 \mathrm{~nm}$ diameter, respectively). The dissolution half-time of an ENM is inversely proportional to its surface area [40]. Concerning comparable masses, as introduced into the dissolution systems in this study, smaller ENMs would be expected to dissolve faster. But size alone does not account for the differences, because the difference remains very significant in surface-normalized dissolution rates. The specific surface area was factored out in the calculation of the dissolution rates from the half-lives, as is routine practice for the CFS results and given in [43].

The maximum temperature that the nanoceria materials were exposed to during preparation may contribute to the dissolution rate difference. Industrially formed nanoceria is often calcined, that is, exposed to temperatures of $400{ }^{\circ} \mathrm{C}$ and more. This is appropriate for nanoceria used as a combustion catalyst, as the calcined surface can become quite active when combustion temperatures are reached. Nanoceria with surface hydroxy groups, as expected for solvothermally synthesized nanoceria, are chemically reactive at physiological temperatures. Increased

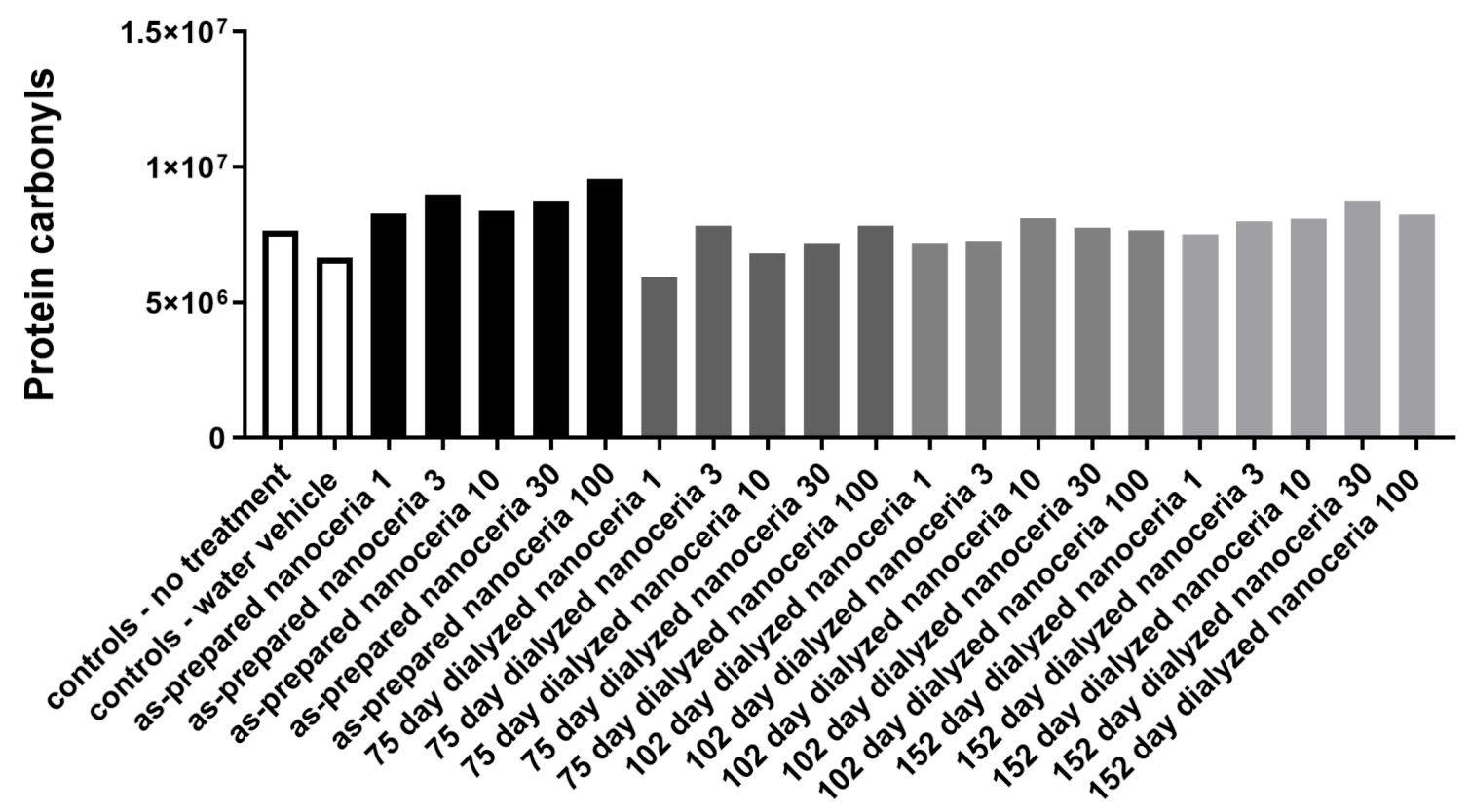

Figure 12: As-prepared and partially dissolved nanoceria altered cell protein carbonyl production. RAW 264.7 cell protein carbonyl production in response to the as-prepared and partially dissolved nanoceria. $X$-axis numbers refer to the nanoceria concentration in $\mu \mathrm{g} / \mathrm{mL}$. Results are the mean of two determinations from one experiment. 


\begin{tabular}{|c|c|c|c|}
\hline name & NM-211 & NM-212 & $\begin{array}{l}\text { solvothermally synthesized } \\
\text { nanoceria }\end{array}$ \\
\hline production process & precipitated & precipitated & solvothermal \\
\hline producer & JRC (Antaria) & JRC (Umicore) & University of Kentucky \\
\hline crystallinity & cubic (cerianite) [7] & cubic (cerianite) $[7,24,51]$ & $\begin{array}{l}\text { hexagonal (cubic fluorite) } \\
{[35,52]}\end{array}$ \\
\hline surface treatment & none & none & citrate [35] \\
\hline impurity (\%) & $\begin{array}{l}\text { ICP-MS: Al } 0.2 \%, 19 \text { other } \\
\text { elements }<0.02 \%[24]\end{array}$ & $\begin{array}{l}\text { ICP-MS: AI } 0.2 \%, 19 \text { other } \\
\text { elements }<0.02 \%[24]\end{array}$ & \\
\hline $\begin{array}{l}\text { surface } \mathrm{Ce}^{3+} \text { oxidation state } \\
\text { (XPS) }\end{array}$ & $5.7 \%[24]$ & $6.9 \%[24]$ & $\begin{array}{l}\text { predominantly } \mathrm{Ce}^{3+} \\
{[35,39,52]}\end{array}$ \\
\hline primary size $\left(\mathrm{D}_{50}\right)(\mathrm{nm})$ & 15 [33] & $40[7,33]$ & $4.2[35,39,52]$ \\
\hline specific surface area $\left(\mathrm{m}^{2} / \mathrm{g}\right)$ & 66 [33] & $27[4,5,7,24,33,36,51]$ & 197 (calculated from TEM) \\
\hline $\begin{array}{l}\text { dissolution rate in PSF } \\
\left(\text { atoms } /\left(\mathrm{h} \cdot \mathrm{nm}^{2}\right)\right)\end{array}$ & 0.00365 & 0.00202 & 0.0144 (monomodal) \\
\hline $\begin{array}{l}\text { FRAS sBOD reactivity (dose } \\
\left.1 \mathrm{~m}^{2} / \mathrm{mL}\right)\left(\mathrm{nmol} \text { TEU } / \mathrm{m}^{2} \text { ENM) }\right.\end{array}$ & $14 \pm 1$ & $13 \pm 1$ & $38 \pm 5\left(@ 0.3 \mathrm{~m}^{2} / \mathrm{mL}\right)$ \\
\hline $\begin{array}{l}\text { FRAS mBOD reactivity (nmol } \\
\text { TEU/mg ENM) }\end{array}$ & $0.9 \pm 0.04$ & $0.3 \pm 0.02$ & $7.5 \pm 1.04$ \\
\hline
\end{tabular}

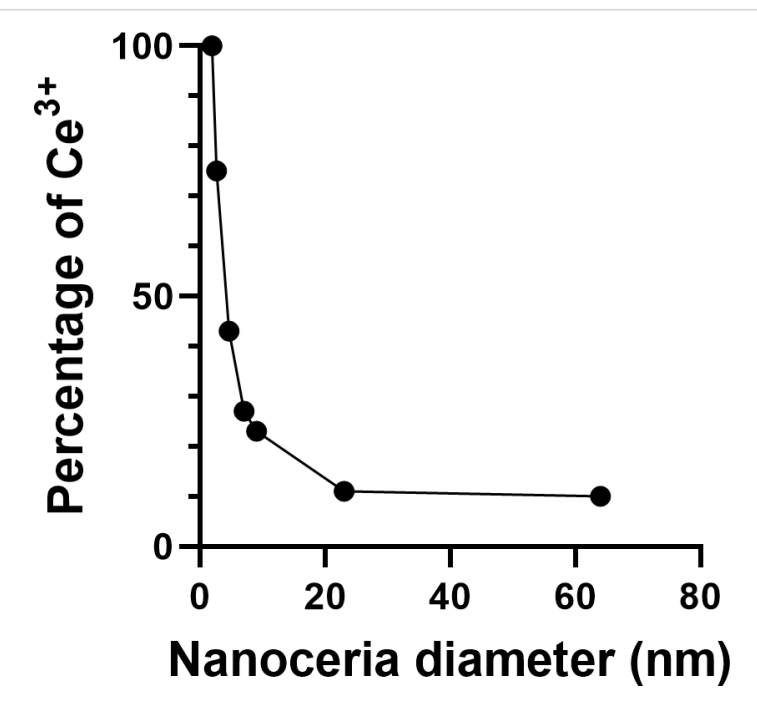

Figure 13: The percentage of surface cerium as $\mathrm{Ce}^{3+}$ as a function of the nanoceria size. Data taken from [55] and [56].

temperature results in water loss as two surface hydroxy groups condense, forming water and a $\mathrm{Ce}-\mathrm{O}-\mathrm{Ce}$ surface site. The amount of surface hydroxy groups decreased as the temperature increased from 200 to $400{ }^{\circ} \mathrm{C}$, with the persistence of some hydroxy groups up to $600{ }^{\circ} \mathrm{C}$ [57]. Reports state that NM-212 was prepared by precipitation [7,24], however, the procedures have not been reported to know if it was precipitated from a liquid or gas phase. If NM-212 was exposed to a high temperature it would be expected to have less surface $\mathrm{Ce}^{3+}$ [58], which is the case (Supporting Information File 1, Table S1), and show slow dissolution, as was seen with NM-212 and the calcined solvothermally synthesized nanoceria.
The cerium valence state difference on the nanoceria surface may contribute to the dissolution rate difference. As the nanoceria size decreases, the $\mathrm{Ce}^{3+} / \mathrm{Ce}^{4+}$ ratio increases (Figure 13). The edge and core of NM-212 had about $90 \% \mathrm{Ce}^{4+}$ whereas the $4 \mathrm{~nm}$ solvothermally synthesized ceria exhibited predominantly $\mathrm{Ce}^{3+}$. Increased $\mathrm{Ce}^{3+}$ is accompanied by an increase in oxygen vacancies that weaken the crystal lattice [14]. According to the dissolution framework by Gray and co-workers, $\mathrm{Ce}^{3+}$ can follow more dissolution pathways (including oxidative dissolution) than $\mathrm{Ce}^{4+}$ [59]. The much greater percentage of $\mathrm{Ce}^{3+}$ on the surface of solvothermally synthesized nanoceria may have contributed to its more rapid dissolution. Although the dissolution rates of NM-211 and NM-212 are similar ([60] and Figure 7), NM-211 dissolved faster. There is significantly more $\mathrm{Ce}^{3+}$ on the surface of NM-211 than on that of NM-212 [7]. Therefore, among these three nanoceria forms, increased surface $\mathrm{Ce}^{3+}$ correlated with a more rapid dissolution.

\section{Role of phosphate in the fate of cerium/ nanoceria}

Precipitation and formation of cerium phosphate particles might contribute to the slow clearance of nanoceria from the lung reported in $[4,9,51,61]$. Cerium ions, introduced as such or released during nanoceria dissolution, in the presence of phosphate form cerium phosphate $[48,52,62-64]$ as was reported after introduction of cerium ions into the lung [65]. After systemic administration of solvothermally synthesized nanoceria, cerium phosphate particles were seen in rat liver and spleen [48,63]. After inhaling $3 \mathrm{mg} / \mathrm{m}^{3} \mathrm{NM}-212$ for two years, $\mathrm{CeO}^{+}$and $\mathrm{CePO}_{4}{ }^{+}$were seen in rat femur [9]. These studies demonstrate a certain extent of dissolution of both nanoceria 
forms in vivo. $\mathrm{Ce}^{3+}$ phosphate is quite insoluble. $\mathrm{Ce}^{4+}$ phosphate is even less soluble ( $\log K_{\mathrm{sp}}=10^{-26}$ to $10^{-23}$ for $\mathrm{Ce}$ (III) phosphate in 0.01 to $12 \mathrm{M} \mathrm{H}_{3} \mathrm{PO}_{4}, 0.1 \mathrm{M} \mathrm{NaH}_{2} \mathrm{PO}_{4}$, or $0.1 \mathrm{M}$ $\mathrm{HCl}$ [66-68]; $\log K_{\mathrm{sp}}=10^{-115}$ for Ce(IV) phosphate in 0.01 to $12 \mathrm{M} \mathrm{H}_{3} \mathrm{PO}_{4}$ and $10^{-34}$ at $\left.\mathrm{pH} 0.4[66,69]\right)$. The present study assessed the hypothesis that phosphate groups not in direct contact with nanoceria would create a sink for released cerium ions and increase the nanoceria dissolution rate. The results do not support the hypothesis. However, while Ce forms a strong complex with orthophosphate anions as indicated by the above $K_{\mathrm{sp}}$ values, it is possible that the complexation constants for the immobilized phosphate groups on the LN resin and HTP are weaker than for $\mathrm{Ce}^{3+}$ and orthophosphate. The results are consistent with a two-step nanoceria dissolution process. First, the cerium ions leave the nanoceria surface, by dissociative dissolution of $\mathrm{Ce}^{4+}$ and oxidative or dissociative dissolution of $\mathrm{Ce}^{3+}$, consistent with the interpretation that nanoceria dissolution occurs at the solid-liquid interface [14]. Cerium ions may then complex with phosphate. Nanoceria dissolution is $\mathrm{pH}$-dependent $([14,39,70]$ and Figure 11). Nanoceria dissolution presumably results from an interaction between the hydrogen ion and the nanoceria surface. A hypothesis is that hydrogen "steals" oxygen from the $\mathrm{Ce}^{3+}$ of the surface $\mathrm{Ce}-\mathrm{O}$ complex, enabling $\mathrm{Ce}^{3+}$ release. This would be consistent with increased dissolution as the $\mathrm{pH}$ value decreases, surface $\mathrm{Ce}^{3+}$ increases, and size decreases (and surface $\mathrm{Ce}^{3+}$ increases). Also, there is more available oxygen on the surface of nanoceria not exposed to high temperature.

\section{Biological identity of as-prepared and partially dissolved nanoceria}

Nanoceria has the potential to act as a pro- or antioxidant, depending on its valence, and the oxidative stress level of the system under study. Solvothermally synthesized nanoceria increased protein carbonyls in rats and Caenorhabditis elegans that were not induced by oxidative stress [71,72]. In models of oxidative stress, nanoceria decreased elevated levels of protein carbonyls in the lung and hippocampus of hypoxic rats [73,74], in the kidney of diabetic mice [75], in murine embryo tissue in a model of gestational diabetes [76], and in the right ventricle of rats with monocrotaline-induced hypertension [77]. It protected against protein carbonyl elevation induced by acrylamide in HepG2 (human liver epithelial) cells [78] and cyclophosphamide in murine testicles [79].

Increased protein carbonyls in RAW 264.7 cells produced by solvothermally synthesized nanoceria are consistent with the ability of nanoceria to act as a pro-oxidant in systems where oxidative stress is at its normal (basal) level. The lower increase of protein carbonyls following the exposure to partially dissolved nanoceria may be due to the increased surface content of $\mathrm{Ce}^{3+}$ providing antioxidant potential. After dialysis in water, the partially dissolved nanoceria rapidly precipitates from the dispersion, presumably due to the loss of surface citrate and reduced surface charge. The particles do not pass through a 0.2 micrometer MWCO filter, suggesting that they were quite large, which may have affected cell uptake. The results illustrate an effect of nanoceria dissolution on its biological identity.

\section{Nanoceria reactivity}

Nanoceria reactivity increased as the content of $\mathrm{Ce}^{3+}$ on the surface increased and the particle size decreased. The solvothermally synthesized nanoceria exhibited the highest mass-based reactivity, followed by the intermediate sized NM-211 and the largest tested nanoceria with the least amount of surface $\mathrm{Ce}^{3+}$, NM-212. As discussed above for the nanoceria dissolution rate, size contributes to the reactivity differences, but is not sufficient to explain them. After normalizing the reactivity to surface-based reactivity, the value for the solvothermally synthesized nanoceria $\left(38 \pm 5 \mathrm{nmol} \mathrm{TEU} / \mathrm{m}^{2}\right)$ was significantly greater than those for the other nanoceria materials $(14 \pm 1$ and $13 \pm 1 \mathrm{nmol} \mathrm{TEU} / \mathrm{m}^{2}$ ). The difference can be attributed to the chemical identity of the nanoceria surface, where surface $\mathrm{Ce}^{3+}$ mediates the redox cycle influencing the reactivity.

\section{Conclusion}

The dissolution study results, when related to the physicochemical properties of the tested nanoceria, indicate that the amount of surface $\mathrm{Ce}^{3+}$ is the primary factor influencing solubility. Higher nanoceria preparation temperature reduces the amount of surface $\mathrm{Ce}^{3+}$, resulting in reduced solubility. The results suggest that NM-212 was exposed to a high temperature, as is common for nanoceria prepared for industrial applications. The results also show the importance of a complete documentation of the preparation procedures. This is an issue with commercially prepared nanoceria that have been used in many studies, for which the preparation procedures are not available. As it is clear that physicochemical properties of nanomaterials influence their fate and behavior, and the preparation method influences their physicochemical properties, documentation of the preparation, including temperature, is needed to fully interpret the relationship between physicochemical properties of nanoceria and their fate and effects.

\section{Supporting Information}

\section{Supporting Information File 1}

Additional experimental data.

[https://www.beilstein-journals.org/bjnano/content/ supplementary/2190-4286-12-43-S1.pdf] 


\section{Acknowledgements}

The authors gratefully acknowledge Marsha L. Ensor, Shristi Shrestha, and Shekinah Alfaro for their excellent contributions to this research.

\section{Funding}

The research leading to these results received funding from the National Institutes of Health [grant agreement No R01GM109195] and the PATROLS project, as part of European Union's Horizon 2020 research and innovation program [grant agreement No 760813]. The content is solely the responsibility of the authors and does not necessarily represent the official views of the National Institutes of Health.

\section{Conflicts of Interest/Competing Interests}

WW and JGK are employees of a company producing and marketing nanomaterials. The other authors declare that they have no relevant financial or non-financial interests to disclose.

\section{ORCID ${ }^{\circledR} \mathrm{iDs}$}

Robert A. Yokel - https://orcid.org/0000-0001-5188-3972 Wendel Wohlleben - https://orcid.org/0000-0003-2094-3260 Johannes Georg Keller - https://orcid.org/0000-0002-4292-2471 Matthew L. Hancock - https://orcid.org/0000-0001-8492-3512 Jason M. Unrine - https://orcid.org/0000-0003-3012-5261 D. Allan Butterfield - https://orcid.org/0000-0003-3254-5286 Eric A. Grulke - https://orcid.org/0000-0002-2982-9037

\section{References}

1. Younis, A.; Chu, D.; Li, S. Cerium oxide nanostructures and their applications. Functionalized Nanomaterials; InTech: Rijeka, Croatia, 2016; pp 53-68. doi:10.5772/65937

2. Feng, X.; Sayle, D. C.; Wang, Z. L.; Paras, M. S.; Santora, B.; Sutorik, A. C.; Sayle, T. X. T.; Yang, Y.; Ding, Y.; Wang, X.; Her, Y.-S. Science 2006, 312, 1504-1508. doi:10.1126/science.1125767

3. OECD, List of manufactured nanomaterials and list of endpoints for phase one of the sponsorship programme for the testing of manufactured nanomaterials: Revision; Series on the Safety of Manufactured Nanomaterials No. 27. https://www.oecd.org/officialdocuments/displaydocument/?cote=env/jm /mono\%282010\%2946\&doclanguage=en (accessed May 18, 2021).

4. Geraets, L.; Oomen, A. G.; Schroeter, J. D.; Coleman, V. A.; Cassee, F. R. Toxicol. Sci. 2012, 127, 463-473. doi:10.1093/toxsci/kfs113

5. Gosens, I.; Mathijssen, L. E. A. M.; Bokkers, B. G. H.; Muijser, H.; Cassee, F. R. Nanotoxicology 2014, 8, 643-653. doi:10.3109/17435390.2013.815814

6. Schwotzer, D.; Ernst, H.; Schaudien, D.; Kock, H.; Pohlmann, G.; Dasenbrock, C.; Creutzenberg, O. Part. Fibre Toxicol. 2017, 14, 23. doi:10.1186/s12989-017-0204-6

7. Keller, J.; Wohlleben, W.; Ma-Hock, L.; Strauss, V.; Gröters, S.; Küttler, K.; Wiench, K.; Herden, C.; Oberdörster, G.; van Ravenzwaay, B.; Landsiedel, R. Arch. Toxicol. 2014, 88, 2033-2059. doi:10.1007/s00204-014-1349-9
8. Landsiedel, R.; Ma-Hock, L.; Hofmann, T.; Wiemann, M.; Strauss, V.; Treumann, S.; Wohlleben, W.; Gröters, S.; Wiench, K.; van Ravenzwaay, B. Part. Fibre Toxicol. 2014, 11, 16. doi:10.1186/1743-8977-11-16

9. Tentschert, J.; Laux, P.; Jungnickel, H.; Brunner, J.; Estrela-Lopis, I.; Merker, C.; Meijer, J.; Ernst, H.; Ma-Hock, L.; Keller, J.; Landsiedel, R.; Luch, A. Nanotoxicology 2020, 14, 554-576. doi:10.1080/17435390.2020.1736355

10. Dhall, A.; Self, W. Antioxidants 2018, 7, 97. doi:10.3390/antiox7080097 11. Inbaraj, B. S.; Chen, B.-H. Asian J. Pharm. Sci. (Amsterdam, Neth.) 2020, 15, 558-575. doi:10.1016/j.ajps.2019.10.005

12. Singh, K. R. B.; Nayak, V.; Sarkar, T.; Singh, R. P. RSC Adv. 2020, 10, 27194-27214. doi:10.1039/d0ra04736h

13. Yokel, R. A.; Hancock, M. L.; Cherian, B.; Brooks, A. J.; Ensor, M. L.; Vekaria, H. J.; Sullivan, P. G.; Grulke, E. A. Eur. J. Pharm. Biopharm. 2019, 144, 252-265. doi:10.1016/j.ejpb.2019.09.023

14. Claparede, L.; Clavier, N.; Dacheux, N.; Moisy, P.; Podor, R.; Ravaux, J. Inorg. Chem. 2011, 50, 9059-9072. doi:10.1021/ic201269c 15. Chen, J.-C.; Chen, W.-C.; Tien, Y.-C.; Shih, C.-J. J. Alloys Compd. 2010, 496, 364-369. doi:10.1016/j.jallcom.2010.01.151

16. Jalilpour, M.; Fathalilou, M. Int. J. Phys. Sci. 2012, 7 (6), 944-948. doi:10.5897/ijps11.131

17. Sifontes, A. B.; Rosales, M.; Méndez, F. J.; Oviedo, O.; Zoltan, T. J. Nanomater. 2013, 265797. doi:10.1155/2013/265797

18. Wu, Z.; Zhang, J.; Benfield, R. E.; Ding, Y.; Grandjean, D.; Zhang, Z.; Ju, X. J. Phys. Chem. B 2002, 106, 4569-4577. doi:10.1021/jp011520z

19. Karakoti, A. S.; Munusamy, P.; Hostetler, K.; Kodali, V.; Kuchibhatla, S.; Orr, G.; Pounds, J. G.; Teeguarden, J. G.; Thrall, B. D.; Baer, D. R. Surf. Interface Anal. 2012, 44, 882-889. doi:10.1002/sia.5006

20. Yokel, R. A.; Hussain, S.; Garantziotis, S.; Demokritou, P.; Castranova, V.; Cassee, F. R. Environ. Sci.: Nano 2014, 1, 406-428. doi:10.1039/c4en00039k

21. Lahive, E.; Jurkschat, K.; Shaw, B. J.; Handy, R. D.; Spurgeon, D. J.; Svendsen, C. Environ. Chem. 2014, 11, 268-278. doi:10.1071/en14028

22. Morel, E.; Dozois, J.; Slaveykova, V. I.; Wilkinson, K. J. Metallomics 2021, 13, mfaa005. doi:10.1093/mtomcs/mfaa005

23. Röhder, L. A.; Brandt, T.; Sigg, L.; Behra, R. Aquat. Toxicol. 2014, 152 , 121-130. doi:10.1016/j.aquatox.2014.03.027

24. Singh, C.; Friedrichs, S.; Ceccone, G.; Gibson, N.; Jensen, K. A.; Levin, M.; Infante, H. G.; Carlander, D.; Rasmussen, K. Cerium Dioxide, NM-211, NM-212, NM-213. Characterisation and test item preparation; Publications Office of the European Union, 2014. doi:10.2788/80203

25. Nemmar, A.; Yuvaraju, P.; Beegam, S.; Fahim, M. A.; Ali, B. H. Oxid. Med. Cell. Longevity 2017, 9639035. doi:10.1155/2017/9639035

26. Nemmar, A.; Al-Salam, S.; Beegam, S.; Yuvaraju, P.; Ali, B. H. Int. J. Nanomed. 2017, 12, 2913-2922. doi:10.2147/ijn.s127180

27. Meldrum, K.; Robertson, S. B.; Römer, I.; Marczylo, T.; Dean, L. S. N.; Rogers, A.; Gant, T. W.; Smith, R.; Tetley, T. D.; Leonard, M. O. Part. Fibre Toxicol. 2018, 15, 24. doi:10.1186/s12989-018-0261-5

28. Nemmar, A.; Al-Salam, S.; Al Ansari, Z.; Alkharas, Z. A.; Al Ahbabi, R. M.; Beegam, S.; Yuvaraju, P.; Yasin, J.; Ali, B. H. Cell. Physiol. Biochem. 2019, 52, 439-454. doi:10.33594/000000032

29. Nemmar, A.; Al-Salam, S.; Beegam, S.; Yuvaraju, P.; Ali, B. H. Biomolecules 2019, 9, 376. doi:10.3390/biom9080376

30. Nalabotu, S. K.; Manne, N. D. P. K.; Kolli, M. B.; Nandyala, G.; Para, R. K.; Rice, K. M.; Jones, C. B.; Blough, E. R. J. Toxicol. Risk Assess. 2019, 5, 26. doi:10.23937/2572-4061.1510026 
31. Meldrum, K.; Robertson, S.; Römer, I.; Marczylo, T.; Gant, T. W.; Smith, R.; Tetley, T. D.; Leonard, M. O. Environ. Toxicol. Pharmacol. 2020, 73, 103273. doi:10.1016/j.etap.2019.103273

32. Idelchik, M. P. S.; Dillon, J.; Abariute, L.; Guttenberg, M. A.; Segarceanu, A.; Neu-Baker, N. M.; Brenner, S. A. J. Microsc. (Oxford, U. K.) 2018, 271, 69-83. doi:10.1111/jmi.12696

33. Wohlleben, W.; Hellack, B.; Nickel, C.; Herrchen, M.; Hund-Rinke, K.; Kettler, K.; Riebeling, C.; Haase, A.; Funk, B.; Kühnel, D.; Göhler, D.; Stintz, M.; Schumacher, C.; Wiemann, M.; Keller, J.; Landsiedel, R.; Broßell, D.; Pitzko, S.; Kuhlbusch, T. A. J. Nanoscale 2019, 11, 17637-17654. doi:10.1039/c9nr03306h

34. Masui, T.; Hirai, H.; Imanaka, N.; Adachi, G.; Sakata, T.; Mori, H. J. Mater. Sci. Lett. 2002, 21, 489-491. doi:10.1023/a:1015342925372

35. Hancock, M. L.; Yokel, R. A.; Beck, M. J.; Calahan, J. L.; Jarrells, T. W.; Munson, E. J.; Olaniyan, G. A.; Grulke, E. A. Appl. Surf. Sci. 2021, 535, 147681. doi:10.1016/j.apsusc.2020.147681

36. Koltermann-Jülly, J.; Keller, J. G.; Vennemann, A.; Werle, K.; Müller, P.; Ma-Hock, L.; Landsiedel, R.; Wiemann, M.; Wohlleben, W. Nanolmpact 2018, 12, 29-41. doi:10.1016/j.impact.2018.08.005

37. Keller, J. G.; Peijnenburg, W.; Werle, K.; Landsiedel, R.; Wohlleben, W. Nanomaterials 2020, 10, 311. doi:10.3390/nano10020311

38. Stefaniak, A. B.; Guilmette, R. A.; Day, G. A.; Hoover, M. D.; Breysse, P. N.; Scripsick, R. C. Toxicol. In Vitro 2005, 19, 123-134. doi:10.1016/j.tiv.2004.08.001

39. Yokel, R. A.; Hancock, M. L.; Grulke, E. A.; Unrine, J. M.; Dozier, A. K.; Graham, U. M. Nanotoxicology 2019, 13, 455-475. doi:10.1080/17435390.2018.1553251

40. Grulke, E. A.; Beck, M. J.; Yokel, R. A.; Unrine, J. M.; Graham, U. M.; Hancock, M. L. Environ. Sci.: Nano 2019, 6, 1478-1492. doi:10.1039/c9en00222g

41. Yokel, R. A.; Florence, R. L.; Unrine, J. M.; Tseng, M. T.; Graham, U. M.; Wu, P.; Grulke, E. A.; Sultana, R.; Hardas, S. S.; Butterfield, D. A. Nanotoxicology 2009, 3, 234-248. doi:10.1080/17435390902974496

42. Keller, J. G.; Graham, U. M.; Koltermann-Jülly, J.; Gelein, R.; Ma-Hock, L.; Landsiedel, R.; Wiemann, M.; Oberdörster, G.; Elder, A.; Wohlleben, W. Sci. Rep. 2020, 10, 458. doi:10.1038/s41598-019-56872-3

43. ISO/TR 19057:2017 Nanotechnologies - Use and application of acellular in vitro tests and methodologies to assess nanomaterial biodurability. https://www.iso.org/standard/63836.html (accessed May 18, 2021)

44. Utembe, W.; Potgieter, K.; Stefaniak, A. B.; Gulumian, M. Part. Fibre Toxicol. 2015, 12, 11. doi:10.1186/s12989-015-0088-2

45. Sultana, R.; Ravagna, A.; Mohmmad-Abdul, H.; Calabrese, V.; Butterfield, D. A. J. Neurochem. 2005, 92, 749-758. doi:10.1111/j.1471-4159.2004.02899.x

46. Gandon, A.; Werle, K.; Neubauer, N.; Wohlleben, W. J. Phys.: Conf. Ser. 2017, 838, 012033 doi:10.1088/1742-6596/838/1/012033

47. EELS of Cerium (Ce). https://www.globalsino.com/EM/page2318.html (accessed Jan 26, 2021).

48. Graham, U. M.; Yokel, R. A.; Dozier, A. K.; Drummy, L.; Mahalingam, K.; Tseng, M. T.; Birch, E.; Fernback, J. Toxicol. Pathol. 2018, 46, 47-61. doi:10.1177/0192623317737254

49. Matei, A.; Țucureanu, V.; Țîncu, B. C.; Popescu, M.; Romanițan, C.; Cernica, I.; Dumitrescu, L. G.

Ann. "Dunarea Jos" Univ. Galati, Fascicle IX 2017, 40, 37-41.
50. Prabaharan, D. M. D. M.; Sadaiyandi, K.; Mahendran, M.; Sagadevan, S. Mater. Res. (Sao Carlos, Braz.) 2016, 19, 478-482. doi:10.1590/1980-5373-mr-2015-0698

51. Molina, R. M.; Konduru, N. V.; Jimenez, R. J.; Pyrgiotakis, G.; Demokritou, P.; Wohlleben, W.; Brain, J. D. Environ. Sci.: Nano 2014, 1, 561-573. doi:10.1039/c4en00034j

52. Yokel, R. A.; Tseng, M. T.; Butterfield, D. A.; Hancock, M. L.; Grulke, E. A.; Unrine, J. M.; Stromberg, A. J.; Dozier, A. K.; Graham, U. M. Nanotoxicology 2020, 14, 827-846. doi:10.1080/17435390.2020.1770887

53. Deshpande, S.; Patil, S.; Kuchibhatla, S. V.; Seal, S. Appl. Phys. Lett. 2005, 87, 133113. doi:10.1063/1.2061873

54. Andreescu, D.; Bulbul, G.; Özel, R. E.; Hayat, A.; Sardesai, N.; Andreescu, S. Environ. Sci.: Nano 2014, 1, 445-458. doi:10.1039/c4en00075g

55. Schwabe, F.; Schulin, R.; Rupper, P.; Rotzetter, A.; Stark, W.; Nowack, B. J. Nanopart. Res. 2014, 16, 2668. doi:10.1007/s11051-014-2668-8

56. Tsunekawa, S.; Sivamohan, R.; Ito, S.; Kasuya, A.; Fukuda, T. Nanostruct. Mater. 1999, 11, 141-147. doi:10.1016/s0965-9773(99)00027-6

57. Janoš, P.; Hladík, T.; Kormunda, M.; Ederer, J.; Štastný, M. Adv. Mater. Sci. Eng. 2014, 706041. doi:10.1155/2014/706041

58. Passacantando, M.; Santucci, S. J. Nanopart. Res. 2013, 15, 1785. doi:10.1007/s11051-013-1785-0

59. Gray, E. P.; Browning, C. L.; Wang, M.; Gion, K. D.; Chao, E. Y.; Koski, K. J.; Kane, A. B.; Hurt, R. H. Environ. Sci.: Nano 2018, 5 , 2545-2559. doi:10.1039/c8en00362a

60. Koltermann-Jülly, J.; Keller, J. G.; Vennemann, A.; Werle, K.; Müller, P.; Ma-Hock, L.; Landsiedel, R.; Wiemann, M.; Wohlleben, W. Nanolmpact 2019, 14, 100154. doi:10.1016/j.impact.2019.100154

61. Yokel, R. A.; Au, T. C.; MacPhail, R.; Hardas, S. S.; Butterfield, D. A.; Sultana, R.; Goodman, M.; Tseng, M. T.; Dan, M.; Haghnazar, H.; Unrine, J. M.; Graham, U. M.; Wu, P.; Grulke, E. A. Toxicol. Sci. 2012, 127, 256-268. doi:10.1093/toxsci/kfs067

62. Zhang, P.; Ma, Y.; Zhang, Z.; He, X.; Zhang, J.; Guo, Z.; Tai, R.; Zhao, Y.; Chai, Z. ACS Nano 2012, 6, 9943-9950. doi:10.1021/nn303543n

63. Graham, U. M.; Tseng, M. T.; Jasinski, J. B.; Yokel, R. A.; Unrine, J. M.; Davis, B. H.; Dozier, A. K.; Hardas, S. S.; Sultana, R.; Grulke, E. A.; Butterfield, D. A. ChemPlusChem 2014, 79, 1083-1088. doi:10.1002/cplu.201402080

64. Graham, U. M.; Jacobs, G.; Yokel, R. A.; Davis, B. H.; Dozier, A. K.; Birch, M. E.; Tseng, M. T.; Oberdörster, G.; Elder, A.; DeLouise, L. From dose to response: In vivo nanoparticle processing and potential toxicity. In Modelling the Toxicity of Nanoparticles; Tran, L.; Bañares, M. A.; Rallo, R., Eds.; Advances in Experimental Medicine and Biology, Vol. 947; Springer: Cham, Switzerland, 2017; pp 71-100. doi:10.1007/978-3-319-47754-1_4

65. Berry, J. P.; Zhang, L.; Galle, P.; Ansoborlo, E.; Hengé-Napoli, M. H.; Donnadieu-Claraz, M. Microsc. Res. Tech. 1997, 36, 313-323. doi:10.1002/(sici)1097-0029(19970215)36:4<313::aid-jemt9>3.0.co;2$\mathrm{m}$

66. Lebedev, I. A.; Kulyako, Y. M. Zh. Neorg. Khim. 1978, 23, 3215-3224. 67. Liu, X.; Byrne, R. H. Geochim. Cosmochim. Acta 1997, 61, 1625-1633. doi:10.1016/s0016-7037(97)00037-9

68. Gausse, C.; Szenknect, S.; Qin, D. W.; Mesbah, A.; Clavier, N.; Neumeier, S.; Bosbach, D.; Dacheux, N. Eur. J. Inorg. Chem. 2016, 4615-4630. doi:10.1002/ejic.201600517

69. Li, K.; Zhao, S.; Ma, J. J. Rare Earths 2005, 23, 51-53. 
70. Dahle, J. T.; Livi, K.; Arai, Y. Chemosphere 2015, 119, 1365-1371. doi:10.1016/j.chemosphere.2014.02.027

71. Hardas, S. S.; Sultana, R.; Warrier, G.; Dan, M.; Florence, R. L.; Wu, P.; Grulke, E. A.; Tseng, M. T.; Unrine, J. M.; Graham, U. M.; Yokel, R. A.; Butterfield, D. A. NeuroToxicology 2012, 33, 1147-1155. doi:10.1016/j.neuro.2012.06.007

72. Arndt, D. A.; Oostveen, E. K.; Triplett, J.; Butterfield, D. A.; Tsyusko, O. V.; Collin, B.; Starnes, D. L.; Cai, J.; Klein, J. B.; Nass, R.; Unrine, J. M. Comp. Biochem. Physiol., Part C: Toxicol. Pharmacol. 2017, 201, 1-10. doi:10.1016/j.cbpc.2017.08.009

73. Arya, A.; Sethy, N.; Singh, S. K.; Das, M.; Bhargava, K. Int. J. Nanomed. 2013, 8, 4507-4520. doi:10.2147/ijn.s53032

74. Arya, A.; Gangwar, A.; Singh, S. K.; Roy, M.; Das, M.; Sethy, N.; Bhargava, K. Int. J. Nanomed. 2016, 11, 1159-1173. doi:10.2147/ijn.s102096

75. Jahani, M.; Shokrzadeh, M.; Vafaei-Pour, Z.; Zamani, E.; Shaki, F. Asian J. Anim. Vet. Adv. 2016, 11, 226-234. doi:10.3923/ajava.2016.226.234

76. Vafaei-Pour, Z.; Shokrzadeh, M.; Jahani, M.; Shaki, F. Iran. J. Pharm. Res. 2018, 17, 964-975. doi:10.22037/ijpr.2018.2253

77. Nassar, S. Z.; Hassaan, P. S.; Abdelmonsif, D. A.; ElAchy, S. N. Life Sci. 2018, 201, 89-101. doi:10.1016/j.Ifs.2018.03.045

78. Azari, A.; Shokrzadeh, M.; Zamani, E.; Amani, N.; Shaki, F. Drug Chem. Toxicol. 2019, 42, 54-59. doi:10.1080/01480545.2018.1477793

79. Hamzeh, M.; Hosseinimehr, S. J.; Karimpour, A.; Mohammadi, H. R.; Khalatbary, A. R.; Amiri, F. T. Int. J. Prev. Med. 2019, $10,5$. doi:10.4103/ijpvm.ijpvm_184_18

\section{License and Terms}

This is an Open Access article under the terms of the Creative Commons Attribution License (https://creativecommons.org/licenses/by/4.0). Please note that the reuse, redistribution and reproduction in particular requires that the author(s) and source are credited and that individual graphics may be subject to special legal provisions.

The license is subject to the Beilstein Journal of Nanotechnology terms and conditions:

(https://www.beilstein-journals.org/bjnano/terms)

The definitive version of this article is the electronic one which can be found at:

https://doi.org/10.3762/bjnano.12.43 